\title{
Identification of Fly Ash and Bottom Ash (FABA) Hazardous Waste Generation From the Industrial Sector and Its Reduction Management in Indonesia
}

I Made Wahyu Widyarsana ( $\sim$ imww.research@gmail.com )

Bandung Institute of Technology: Institut Teknologi Bandung https://orcid.org/0000-0003-2337-8500

Suci Ameliya Tambunan

Bandung Institute of Technology: Institut Teknologi Bandung

Aurilia Ayuanda Mulyadi

Bandung Institute of Technology: Institut Teknologi Bandung

\section{Research Article}

Keywords: Industrial sector, Fly ash, Bottom ash, Prediction, Utilization

Posted Date: March 18th, 2021

DOl: https://doi.org/10.21203/rs.3.rs-307109/v1

License: (c) (i) This work is licensed under a Creative Commons Attribution 4.0 International License.

Read Full License 


\title{
Identification of fly ash and bottom ash (FABA) hazardous waste generation from the industrial sector and its reduction management in Indonesia
}

\author{
I Made Wahyu Widyarsana $^{1 *}$, Suci Ameliya Tambunan ${ }^{2}$, Aurilia Ayuanda Mulyadi $^{3}$ \\ ${ }^{1,2,3}$ Faculty of Civil and Environmental Engineering, Bandung Institute of Technology, \\ Bandung, Indonesia
}

\begin{abstract}
With increasing economic growth and urbanization, it is estimated that the amount of waste in Indonesia will increase. One big player in the industrial sector is the energy procurement industry. This research was conducted to determine the generation of fly ash and bottom ash (FABA) in Indonesia using 3 (three) data approaches: (1) the industrial production capacity of the energy supply sector in the form of Steam Power Plants (SPP), (2) hazardous waste generation data in the Mining, Energy, Oil, and Gas (MEOG) Industry and (3) the hazardous waste generation data in the Manufacturing, Agro-industry, and Service (MAS) Industry, with the data obtained from the Ministry of Environment and Forestry. Furthermore, the FABA generation will be predicted until 2040, and the management of the waste will also be discussed. It is known that Indonesia's SPP sector has a production capacity of $69,600,000$ tonnes $\mathrm{yr}^{-1}$, with the waste factor for fly ash and bottom ash being 0.0653 and 0.0091 respectively. Thus, based on the maximum and minimum capacity, the total bottom ash and fly ash may reach 5,186,334.09 tonnes $\mathrm{yr}^{-1}$, and 3,630,433.86 tonnes $\mathrm{yr}^{-1}$ in 2019 respectively. Furthermore, the FABA generation in 2019 from the MEOG and MAS sector reached 7,381,414.47 tonnes and 21,764,718.79 tonnes respectively. Meanwhile, the Annual Average Growth Rate prediction method determined that the FABA generation in the SPP sector is in the range of 3,668,744.62 tonnes to 5,241,063.75 tonnes in 2040. The FABA generated from MEOG and MAS sectors is assumed to be in the range of 7.459.308,07 tonnes to 21.994.394,61 tonnes in 2040. Apart from the disposal technology, FABA waste can also be utilized; fly ash can be used as hot mix asphalt, cement and concrete, and landfill cover. Meanwhile, bottom ash can be widely used in road construction projects as a substitute for aggregates due to its sand-like properties and substitute for aggregate in concrete mixtures.
\end{abstract}

Keywords: Industrial sector, Fly ash, Bottom ash, Prediction, Utilization

\section{Introduction}

Increasing economic growth and urbanization implicates increasing waste in Indonesia as well. One constantly increasing waste comes from the industrial sector. Industrial waste refers to all the waste from industrial operations or derived from the manufacturing process as reported by Jasem et al. [1]. One big player in the industrial sector is the energy procurement industry. Indonesia's energy demand is currently estimated to be equivalent to 1,050.3 million oil barrels, with $50 \%$ being imported as reported by Permana et al. [2]. Currently, there are many plans to build several new Steam Power Plants (SPP) with a total capacity of 35,000 MG or $35 \mathrm{GW}$, both inside and outside Java as reported by Damayanti [3]. Steam Power Plants (SPP) in the energy procurement sector mainly use coal as their fuel. From this activity, hazardous and toxic waste will be produced in the form of fly ash and bottom ash (FABA), of which the management is regulated in Governmental Decree Number 101 of 2014.

\footnotetext{
*Correspondence: imww.research@gmail.com
} 
The consumption of coal in the boiler produces 2 (two) main wastes, which are bottom ash and fly ash in the range of 10-30 as reported by Levandowski and Kalkreuth [4] and 70-90\% as reported by Lynn et al. [5] respectively. Indonesia's plan to develop SPP and increase its total capacity will result in coal still being the main fuel for energy procurement industries, implying a significant increase in its fly ash and bottom ash hazardous waste. The SPP, as the biggest FABA generator, will be the biggest contributor to environmental problems if fly ash and bottom ash are not handled properly.

Large amounts of coal ash are usually stored in piles, and if contaminated, can pose a serious threat to the environment and human health as reported by Damayanti [3]. Globally, there has been an increase in the production of fly ash and bottom ash. The increase in bottom ash is shown in Table 1 below. Table 1 elucidates the considerable amount of fly ash and bottom ash; one way to control FABA generation is by utilization. In recent years, the utilization of bottom ash in the engineering field has received considerable attention due to its potential application as reported by Abdullah et al. [11].

This research was conducted to determine Indonesia's FABA generation using several data approaches; (1) the industrial production capacity of the energy supply sector in the form of Steam Power Plants, (2) hazardous waste generation data in the Mining, Energy, Oil, and Gas (MEOG) Industry and (3) the hazardous waste generation data in the Manufacturing, Agroindustry and Service (MAS) Industry with data obtained from the Ministry of Environment and Forestry. Furthermore, this FABA generation will be predicted until 2040, and the management of the waste will also be discussed. This research is hoped to be used as a reference in policymaking and concrete steps for central and local governments regarding hazardous waste management.

\section{Materials and methods}

The fly ash and bottom ash generation will be obtained using several data approaches; (1) the industrial production capacity of the energy supply sector in the form of Steam Power Plants, (2) hazardous waste generation data in the MEOG Industry and (3) the hazardous waste generation data in the MAS Industry with data obtained from the Ministry of Environment and Forestry. Calculating FABA generation is done by categorizing industry types following the Indonesian Standard Classification of Business Fields (ISCBF). In the industry categorization, the production capacity is obtained based on Industrial Production Capacity from the Ministry of Industry Performance Report from 2015 to 2019. The detailed data on industrial production in Indonesia can be seen in Table 2 below.

Table 2 shows that the SPP sector has a production capacity of 69,600,000 tonnes/year. This value will then be used as the basis for calculating the FABA generation in Indonesia. The maximum and minimum production value of FABA from the SPP activity is also assumed; the maximum capacity of FABA is assumed to be the entire production capacity of SPP activities, while the minimum capacity for FABA is assumed to be $70 \%$ of the total production capacity of the SPP activities. This value will then be multiplied by the waste factor of the Indonesian SPP sector. These calculations will result in the value of FABA generation using the SPP production capacity approach in Indonesia, as shown in Equation (1) and (2) below.

Maximum $H W G=P C \times W F$

Minimum $H W G=P C \times 0.7 \times W F$

\section{Where:}

Maximum HWG = Maximum hazardous waste generation (tonnes $\mathrm{yr}^{-1}$ )

$\mathrm{PC}$

WF

$=$ Production capacity (tonnes $\mathrm{yr}^{-1}$ )

$=$ Waste factor 
Furthermore, the prediction of FABA waste will be carried out using the Annual Average Growth Rate. In this method, the predicted annual hazardous waste production was calculated by multiplying the base-year industrial hazardous waste production by the annual average growth rate index of hazardous waste production in the predicted period [13]. The prediction model is shown in Equation (3) below.

$$
W_{n}=W_{0} x(1+\mu)^{n}
$$

Where:

$W_{n} \quad=$ predicted annual industrial hazardous waste production (tonnes/year)

$W_{0} \quad=$ base year production of industrial hazardous waste, (tonnes/year)

$\mu \quad=$ annual average growth rate of industrial hazardous waste in the predicted period $\mathrm{n} \quad=$ year

With this method, it is assumed that the annual average growth of FABA in Indonesia is $5 \%$. This value is adapted to the increasing demand for coal as a fuel for energy procurement. In the past decade, there has been a tremendous increase in fly ash generation since coal-based thermal power plants meet more than $70 \%$ of electricity demand. In terms of energy, the annual increase in power generation is 5\% as reported by Mandal and Sinha [14], while coal production's annual increase is 5\% and expected to last for another 40-50 years as reported by Tiewsoh et al. [15]. Thus, it is assumed that the increase of FABA generation will be in line with the increase in coal production for energy procurement, which is $5 \%$. The Annual Average Growth Rate Method is used because of its accuracy in long-term predictions, does not require much data or coefficients, and is relevant to many metric analyses that calculate growth rates.

\section{Results and discussion}

\subsection{Analysis of Fly Ash and Bottom Ash Generation}

As mentioned in the previous section, the fly ash and bottom ash generation will be obtained using several data approaches. The Governmental Decree Number 101 of 2014 accentuates that SPP is one of Indonesia's largest FABA producing sectors. Table 1 further identified that Indonesia's SPP production capacity reaches $69,600,000$ tonnes $\mathrm{yr}^{-1}$. This value will then be calculated by considering the waste factor of FABA from SPP activities in Indonesia. The waste factor value is taken from the waste factor approach of several companies engaged in power generation activities. The waste factor of fly ash is obtained from the waste factor of the power plant industry of Indonesia Power Company of 0.034 and Pembangkit Jawa Company of 0.096. Meanwhile, the waste factor for bottom ash is also obtained from these 2 (two) companies, with a value of 0.0008 and 0.0173 , respectively. Therefore, these 2 (two) waste factors conclude that the waste factor for fly ash in Indonesia is 0.0653 and the waste factor for bottom ash is 0.0091 . The resulting fly ash and bottom ash generation in the base year of 2019 are shown in Table 3 and Table 4 below.

Table 3 and Table 4 show that fly ash generation reaches 4,550,615.33 tonnes $\mathrm{yr}^{-1}$ and bottom ash generation reaches $635,718.76$ tonnes $\mathrm{yr}^{-1}$ based on the maximum capacity. Meanwhile, fly ash generation reaches 3,185,430.73 tonnes $\mathrm{yr}^{-1}$, and bottom ash generation reaches $445,003.13$ tonnes $\mathrm{yr}^{-1}$ based on the minimum capacity. Thus, based on the maximum capacity, the total FABA generation reaches 5,186,334.09 tonnes $\mathrm{yr}^{-1}$ and based on the minimum capacity, the total FABA generation reaches 3,630,433.86 tonnes $\mathrm{yr}^{-1}$.

The data approach from the Mining, Energy, Oil, and Gas (MEOG) sector and Manufacturing, Agro-industry, and Service (MAS) sector are obtained from the Ministry of Environment and Forestry through the SIRAJA platform. This platform is used by producers of hazardous waste in the industrial sector to report their hazardous waste generation and the 
management system. However, based on the 2020 Ministry's report, only 15,455 industries submitted their hazardous waste reports, while the Economic Census in 2016 highlighted that 18.933.219 industries have the potential to generate hazardous waste, including the Micro and Small Enterprises (MSEs) and Medium and Large Enterprises (MLEs). Accordingly, the FABA generation from 2016 to 2019 can be seen in Table 5 below and shows that the FABA generation in the base year of 2019 from the MEOG Sector reaches 7,381,414.47 tonnes and from the FABA generation from MAS Sector reaches 21,764,718.79 tonnes.

\subsection{Analysis of the Data Characteristics of Fly Ash and Bottom Ash Generation}

The characteristics of fly ash and bottom ash generation data from MEOG and MAS sectors can be analyzed through statistical analysis, which can help determine the relationship between 2 (two) data. Relationships between data can verify the combined range of FABA generation of both sectors. This can be done through the comparative test, which can help determine the significance of the mean difference between the 2 (two) independent data.

Before doing the comparative test, it is crucial to do a normality test to determine whether the data is normally distributed or not. It is done to determine the suitable data testing method in parametric statistical analysis. If the data is not normally distributed, then the research hypothesis is tested using a non-parametric statistical analysis approach. One factor of test selection for data processing is the number of tested samples. The Shapiro - Wilk test has a stable probability value for a sample size of 7 to 50 as reported by Santoso [16]. Thus, a normality test was carried out using Shapiro - Wilk method in this study. The data normality of FABA generation in both MEOG and MAS sectors is shown in Table 6 below.

Table 6 displays that the significance value of MEOG data is 0.611 and 0.074 for MAS data. The data characteristics are determined from the resulting significance value. A data set is categorized as fairly normally distributed if it has a significance value above 0.05 . Thus, the table above concludes that the FABA generation data from MEOG and MAS sectors are normally distributed, and a comparative analysis of the 2 (two) generation data can be done using parametric analysis.

The comparative test was carried out using the Independent T-Test method. This test was conducted to determine whether there was a significant difference between the 2 (two) independent data groups. The 2 (two) independent data groups in question are 2 (two) unpaired groups, meaning that the data sources come from different subjects. The prerequisite data assumptions are: the tested data group must be independent or unpaired data, the data per group has to be normally distributed, no outlier data in the data groups, and variance between groups is the same or homogenous.

Regarding the requirement above, the tested data on FABA waste generation from MEOG and MAS sectors was independent and unpaired because they come from 2 (two) different sources. The FABA generation data is normally distributed and has no outlier after being tested using the Shapiro - Wilk method. Furthermore, before starting the Independent T-Test, it must be known whether the data variance between the groups is homogeneous. The 2 (two) data groups will be tested using statistical software, and the results can be seen in Table 7 below.

Table 7 highlights that the homogeneity of data can be seen from the value of Levene's Test for Equality of Variances. The data is said to be homogeneous if the significance value of Levene's Test is above 0.05 . Therefore, Table 7 shows that the significance value of Levene's Test is 0.128 and is greater than 0.05 making the 2 (two) data categories homogeneous.

As the 2 (two) groups of data have been proven to have homogeneous properties, the Independent Sample T-Test can be done. Before analysis, an initial hypothesis (H0) must be made, which will be used as a parameter of this test. As this test will reveal the relationship between the 2 (two) samples, the initial hypothesis is that there is no difference between the average FABA generation by the MEOG and MAS sectors, while the opposite hypothesis ( $\mathrm{Ha})$ 
states that there is a difference between the average FABA generation by the MEOG and MAS sectors.

The Independent T-Test results in Table 7 revealed that the Asymp. Sig (2-tailed) of the data is 0.176 or greater than 0.05 , and it can be interpreted that the value of the hypothesis $(\mathrm{Ha})$ is rejected and the hypothesis (H0) is accepted as reported by Graventter and Wallnau [17]; in other words, there is no significant difference in the FABA average generation between the MEOG and MAS sectors. It can be concluded that the FABA generated by the MEOG and MAS sectors do not have significant differences from each other and can be used as a range of FABA generation values in Indonesia.

\subsection{The Prediction of Fly Ash and Bottom Ash Generation}

After determining the FABA generation in the base-year, a prediction of FABA waste generation was carried out to determine FABA generation until 2040 on each data approach. This prediction is carried out using the Annual Average Growth Rate method with the assumptions described previously. The first prediction is carried out to predict FABA generation using the maximum and minimum production capacity data in Indonesia until 2040, with the result shown in Table 8 below.

Table 8 shows that the FABA generation in 2040 from the maximum production capacity approach reaches 5,241,063.75 tonnes and 3,668,744.62 tonnes for the minimum production capacity approach. Both data approaches show an increase in FABA generation by $1.04 \%$ from 2019 to 2040, as shown in Figure 1 and Figure 2 below.

It can be concluded that, for the industrial sector in the SPP business sector, the FABA waste generation range from 3,630,433.86 tonnes to 5,186,334.09 tonnes in 2019 and 3,668,744.62 tonnes to 5,241,063.75 tonnes in 2040. Furthermore, the FABA generation prediction was carried out using the maximum and minimum production capacity approach. The prediction results of FABA generation until 2040 using the data approach from the MEOS sector can be seen in Table 9 below.

Table 9 shows that the FABA generation in 2040 from the MEOG sector reaches 7,459,308.07 tonnes. This data approach demonstrates an increase in FABA generation by $1.04 \%$ from 2019 to 2040, as shown in Figure 3 below. Furthermore, the prediction results of FABA until 2040 using data from the MAS sector can be seen in Table 10 below, and shows that the FABA generation in 2040 from the MAS sector reaches 21,994,394.61 tonnes. This approach demonstrates an increase in FABA generation by 1.04\% from 2019 to 2040, as seen in Figure 4 below.

Thus, for the industrial sector using the MEOG sector approach, the FABA generation reaches 7,459,308.07 tonnes in 2040, and the FABA generation from the MAS sector reaches 21,994,394.61 tonnes in 2040. As the FABA generation from MEOG and MAS sectors does not significantly differ, Indonesia's industrial sector generation can be assumed to be in the range of 7,459,308.07 tonnes to 21,994,394.61 tonnes in 2040. However, the range of FABA generation above is only based on the Ministry's data. As previously mentioned, not all industries that produce hazardous waste report their management system to the Ministry of Environment and Forestry - making the actual condition of fly ash and bottom ash generation in Indonesia to be much greater than the value stated in this study.

The map of the distribution of FABA producing locations in 34 (thirty-four) provinces in Indonesia is shown in Fig.5. The figure below shows that the FABA producing industries in Indonesia are not evenly distributed. Industries engaged in energy procurement and producing FABA are dominated in Java: in the Provinces of West Java, East Java, and Central Java, which have about 3,000 to 5,000 energy procurement industries that generate FABA. Meanwhile, the smallest FABA generators are in the Provinces of North Kalimantan, Maluku, North Maluku, Papua, and West Papua, which have about 50 to 100 FABA-producing industries. 


\subsection{Fly Ash and Bottom Ash Waste Management}

Based on the Appendix of Governmental Decree Number 101 of 2014, fly ash is waste from coal-burning at Steam Power Plants (SPP) facilities, boilers, and/or industrial furnaces. Fly ash is coded as B409 in the Appendix and is included as a category 2 waste and categorized as hazardous waste. Meanwhile, bottom ash is coded as B410 in the Appendix. Bottom ash generated from the operation of the waste incinerator is included in hazard category 1, while the bottom ash generated from the coal burning process at SPP facilities, boilers, and/or industrial furnaces is included in hazard category 1.

As previously stated, FABA generation will increase over time. The most widely practiced FABA disposal technology is the separation process, solidification/stabilization methods, and thermal method as reported by Sun et al. [18]. The Separation Process aims to reduce the chloride, salts, alkali, and heavy metals in MSWI fly ash and improve MSWI fly ash quality. Solidification/stabilization (SS) methods are one of the main international methods at present. This method aims to prevent fly ash from moving before entering the landfill or before it is utilized. This stabilization and solidification process can be carried out in 2 (two) methods: cement solidification and chemical stabilization. Meanwhile, thermal methods treat fly ash by heating it to control the waste to prevent a leaching process. This method also has the highest reduction rate among other disposal methods.

This increasing FABA generation is in line with the increasing costs for FABA management; the more the generation, the more the costs of clearing new landfills, transporting FABA waste to disposal facilities, and monitoring reclamation facilities. Therefore, the utilization of FABA waste is currently a new option; moreover, FABA can indeed be reused, especially in civil engineering and agriculture and the manufacturing of soil products industry as reported by Ramme and Tharaniyil [19].

Utilization of fly ash is mostly used as hot mix asphalt, cement and concrete, and landfill cover as reported by Sun et al. [18]. Based on research, the usage of fly ash enhanced the physical and mechanical properties of concrete as reported by Amin and Abdelsalam [20]. Meanwhile, bottom ash is widely used in road construction projects as a substitute for aggregates due to its sand-like properties and as a substitute for aggregate in concrete mixtures. Environmentally speaking, fly ash, and bottom ash can be a potential solution in FABA disposal activities. Some of the uses of FABA can be seen in Figure 6 below.

Before carrying out this utilization activity, the FABA content and the potential environmental pollution must be identified. The chemical components of bottom ash in Indonesia can be seen in Table 11 below. In general, the bottom ash content is usually dominated by silica, alumina, iron, and calcium oxide. Before bottom ash and fly ash is to be utilized, heavy metal content must be considered. The reactivity and potential hazards of heavy metals released into the environment from the reaction of fly ash and bottom ash with $\mathrm{CO}_{2}$ and water during utilization will decrease over time, enabling FABA components to become more stable and less harmful to the environment as reported by Abdullah et al. [11]. The many advantages of fly ash and bottom ash have pushed many countries to implement their respective FABA utilization policies. To be considered harmless, FABA must meet the TCLP test limits.

The Governmental Decree Number 101 of 2014 includes FABA as hazardous waste; as such, its utilization is very limited, only reaching $10 \%$ of FABA production in Indonesia. However, a new regulation has risen regarding the hazardous waste in Governmental Decree Number 101 of 2014 as stated in the Ministry of Environment and Forestry Decree Number 10 of 2020, in a prospect in delisting some waste to non-hazardous, including nickel slag, fly ash from the coal burning process at SPP facility, steel slag, and spent bleaching earth. As of 2021, a new regulation has been officiated regarding Environmental Protection and Management Implementation in Governmental Decree Number 22 of 2021. This regulation states that fly 
ash and bottom ash has been listed as listed non-hazardous waste in the regulation's appendix, along with steel slag, nickel slag, mill scale, Electric Arc Furnace (EAF) dust, PS ball, spent bleaching earth, and sand foundry. The government has made efforts to increase bottom ash utilization because of its enormous potential to be exploited as stated in the regulation. The listed non-hazardous waste, or in this condition, fly ash and bottom ash, can be utilized as raw materials, substitution of raw materials, energy substitution, and by products.

Based on the regulation, the substitution of raw materials of fly ash and bottom ash can be used in making concrete, bricks, paving blocks, lightweight concrete and other similar construction materials, cement industry, soil compaction, and other forms are in accordance with the development of science and technology. As energy substitute, FABA can be used as fuel. The FABA management process starting from storage, transportation, utilization, and landfilling has also been simplified into:

1. Storage does not require a permit

2. No specific transportation specifically from the Ministry of Environment and Forestry

3. Utilization does not require a utilization permit but requires a standard from the agency involved

4. Landfilling does not require permission

This regulation is expected to increase the utilization rate of fly ash an bottom ash waste, and reduce the risk of environmental pollution, given the high value of waste utilization, which can provide benefits for many parties, as has been done in several countries in the world.

\section{Conclusion}

With increasing economic growth and urbanization, it is estimated that the amount of waste in Indonesia will increase. One big player in the industrial sector is the energy procurement industry. Currently, there are many plans to build several new Steam Power Plants (SPP) with a total capacity of 35,000 MG or $35 \mathrm{GW}$, both inside and outside Java. This research was conducted to determine the generation of Fly Ash and Bottom Ash (FABA) in Indonesia using 3 (three) data approaches: (1) the industrial production capacity of the energy supply sector in the form of Steam Power Plants (SPP), (2) hazardous waste generation data in the Mining, Energy, Oil, and Gas (MEOG) Industry and (3) the hazardous waste generation data in the Manufacturing, Agro-industry, and Service (MAS) Industry, with the data obtained from the Ministry of Environment and Forestry. Furthermore, this FABA generation will be predicted until 2040, and the management of the waste will also be discussed. It is known that Indonesia's SPP sector has a production capacity of $69,600,000$ tonnes $\mathrm{yr}^{-1}$, with the waste factor for fly ash being 0.0653 and the waste factor for bottom ash is 0.0091 . Thus, based on the maximum capacity, the total bottom ash and fly ash may reach 5,186,334.09 tonnes $\mathrm{yr}^{-1}$, and based on the minimum capacity, the total bottom ash and fly ash was 3,630,433.86 tonnes $\mathrm{yr}^{-1}$ in 2019 . Furthermore, the FABA generation in 2019 from the MEOG sector reached 7,381,414.47 tonnes, and the MAS sector reached 21,764,718.79 tonnes. Meanwhile, the Annual Average Growth Rate prediction method determined that the FABA generation in the SPP sector is in the range of 3,668,744.62 tonnes to 5,241,063.75 tonnes in 2040. On the other hand, the statistical analysis using Shapiro - Wilk Normality Test and Independent T-Test concluded that the FABA generated by the MEOG and MAS sectors has no significant differences. The FABA generated from MEOG and MAS sectors is assumed to be in the range of 7.459.308,07 tonnes to 21.994.394,61 tonnes in 2040. Apart from the disposal technology, FABA waste can also be utilized; fly ash can be used as hot mix asphalt, cement and concrete, and landfill cover. Meanwhile, bottom ash can be widely used in road construction projects as a substitute for aggregates due to its sand-like properties and substitute for aggregate in concrete mixtures. This research is hoped to be used as a reference in policymaking and become concrete steps for the central and local governments regarding hazardous waste management. 


\section{Declarations}

346 Availability of data and materials

347 All data generated or analyzed during this study are available upon request.

\section{Competing interest}

349 The authors declare they have no competing interests.

\section{Funding}

This work was not supported by any funding source.

\section{Authors' contributions}

I Made Wahyu Widyarsana provided the data, processed the data, and wrote the draft. Suci Ameliya Tambunan fulfilled the analysis, processed the data, wrote the draft, and performed proofreading. Aurilia Ayuanda Mulyadi performed proofreading. All authors read and approved the final manuscript.

358 Not applicable.

359

360

361

362

363

\section{References}

1. Jasem M, Alhumoud, Fatima A, Kandari A. Analysis and overview of industrial solid waste management in Kuwait. Management of Environmental Quality: An International Journal. 2008; 19(5):520-532. doi:10.1108/147778308 10894210.

2. Permana AD, Sugiyono A, Suharyono H, Boedoyo MS. Indonesia's energy outlook 2010: Technology to support the reliability of electrical energy supply. Jakarta: BPPT-Press; 2010 [in Bahasa Indonesia].

3. Damayanti R. Abu batubara dan pemanfaatannya: Tinjauan teknis karakteristik secara kimia dan toksikologinya. J Teknol Miner dan Batubara. 2018;14(3):213-231. doi:10.30556/jtmb.vol14.no3.2018.966.

4. Levandowski J, Kalkreuth W. Chemical and petrographical characterization of feed coal, fly ash and bottom ash from the Figueira Power Plant, Paraná, Brazil. International Journal of Coal Geology. 2009;77(3-4):269-81.

5. Lynn CJ, Ghataora GS, Dhir OBE RK. Municipal incinerated bottom ash (MIBA) characteristics and potential for use in road pavements. Int J Pavement Res Technol. 2017;10(2):185-201. doi:10.1016/j.ijprt.2016.12.003

6. American Road \& Transportation Builders Association. Production and use of coal combustion products in the U.S. - market forecast through 2033. Am Coal Ash Assoc. 2015;(june):74 ppgs.

7. Abis M, Bruno M, Kuchta K, et al. Assessment of the synergy between recycling and thermal treatments in municipal solid waste management in Europe. Energies. 2020;13(23):6412. doi:10.3390/en13236412.

8. Ma S-H, Xu M-D, Qiqige, Wang X-H, Zhou X. Challenges and developments in the utilization of fly ash in China. Int $J$ Environ Sci Dev. 2017;8(11):781-785. doi:10.18178/ijesd.2017.8.11.1057.

9. Singh G, Kumar S, Mohapatra SK, Kumar K. Comprehensive characterization of grounded bottom ash from indian thermal power plant. J Residuals Sci Technol. 2017;14(1):1-10. doi:10.12783/issn.1544-8053/14/1/1.

10. Izquierdo M, Vazquez E, Querol X, Barra M, Lopez A, Plana F. 2001 Use of bottom ash from municipal solid waste incineration as a road material. In: 4th International ash utilization symposium. Lexington; 2001.

11. Abdullah MH, Rashid ASA, Anuar UHM, Marto A, Abuelgasim R. Bottom ash utilization: A review on engineering applications and environmental aspects. IOP Conf Ser Mater Sci Eng. 2019;527(1). doi:10.1088/1757-899X/527/1/012006. 
12. Ministry of Industry. Ministry of Industry performance report 2015 - 2019. Ministry of Industry. Published online 2019:1-128. https://kemenperin.go.id/download/21250/Laporan-Kinerja-Kementerian-Perindustrian2018 [In Bahasa Indonesia].

13. Liu S, Cheng L, Chen P, Xu S, Gao J, Lu J. Prediction of industrial hazardous waste production based on different models. IOP Conf Ser Earth Environ Sci. 2019;384(1). doi:10.1088/1755-1315/384/1/012026.

14. Mandal AK, Sinha OP. Review on current research status on bottom ash: An indian prospective. J Inst Eng Ser A. 2014;95(4):277-297. doi:10.1007/s40030-014-0100-0.

15. Tiewsoh LS, Jirásek J, Sivek M. Electricity generation in India: Present state, future outlook and policy implications. Energies. 2019;12(7):1-14. doi:10.3390/en12071361.

16. Santoso S. Complete guide to SPSS version 20. Revised ed. Jakarta: Elex Media Komputindo; 2014 [in Bahasa Indonesia].

17. Graventter and Wallnau. Statistics for the behavioral sciences. 10th ed. Wadsworth: Cengage Learning; 2017.

18. Sun X, Li J, Zhao X, Zhu B, Zhang G. A review on the management of municipal solid waste fly ash in American. Procedia Environ Sci. 2016;31:535-540. doi:10.1016/j.proenv.2016.02.079

19. Ramme B, Tharaniyil M. Coal combustion products utilisation handbook. Published online 2013:1-448.

20. Amin M, Abdelsalam BA. Efficiency of rice husk ash and fly ash as reactivity materials in sustainable concrete. Sustain Environ Res. 2019;1(1):1-10. doi:10.1186/s42834-0190035-2. 
Table 1 Bottom ash production

417

\begin{tabular}{cc}
\hline Country & Bottom Ash Generation (tonnes yr-1) \\
\hline USA [6] & 10 million \\
Europe [7] & 19 million \\
China [8] & About 60 million \\
India [9] & 100 million \\
Catalonia, Spain [10] & thousand \\
\hline
\end{tabular}

418

Table 2 Information on industrial production capacity [12]

420

\begin{tabular}{cc}
\hline Types of Industry & Production Capacity (tonnes yr ${ }^{-1}$ ) \\
\hline Palm Oil Processing & $6,400,000$ \\
Biodiesel & $16,000,000$ \\
Urea Fertilizer & $9,740,000$ \\
Rayon Fiber & 729,900 \\
Cement & $5,000,000$ \\
Coal & $610,000,000$ \\
Tin & 76,101 \\
Pulp \& Paper & $16,000,000$ \\
Petrochemical & $10,686,800$ \\
Aluminum Smelting & 317,000 \\
Steel & $10,000,000$ \\
Nickel & $34,000,000$ \\
Steam Power Plants (SPP) & $69,600,000$ \\
Leather Tanning & 70,000 \\
Zinc Smelting & 450,000
\end{tabular}

421

422

423

Table 3 Calculation results of FABA generation based on maximum capacity in 2019

\begin{tabular}{|c|c|c|c|c|c|}
\hline $\begin{array}{l}\text { Waste } \\
\text { Types }\end{array}$ & $\begin{array}{c}\text { Potential } \\
\text { Source of } \\
\text { Waste Based } \\
\text { on Gov. } \\
\text { Decree } 101 \text { of } \\
2014\end{array}$ & $\begin{array}{l}\text { Production } \\
\text { Capacity } \\
\left.\text { (tonnes yr }{ }^{-1}\right)\end{array}$ & $\begin{array}{l}\text { Maximum } \\
\text { Production } \\
\text { Capacity } \\
\text { (tonnes yr-1) }\end{array}$ & $\begin{array}{c}\text { Waste } \\
\text { Factor per } \\
\text { Production } \\
\text { Capacity }\end{array}$ & $\begin{array}{l}\text { Base Year } \\
\text { Maximum } \\
\text { Generation } \\
\text { (tonnes yr }{ }^{-1} \text { ) }\end{array}$ \\
\hline Fly Ash & \multirow[b]{2}{*}{$\mathrm{SPP}$} & $69,600,000.00$ & $69,600,000.00$ & 0.07 & $4,550,615.33$ \\
\hline $\begin{array}{c}\text { Bottom } \\
\text { Ash }\end{array}$ & & $69,600,000.00$ & $69,600,000.00$ & 0.01 & $635,718.76$ \\
\hline \multicolumn{6}{|c|}{ Table 4 Calculation results of FABA generation based on minimum capacity in 2019} \\
\hline $\begin{array}{l}\text { Waste } \\
\text { Types }\end{array}$ & $\begin{array}{c}\text { Potential Source } \\
\text { of Waste Based } \\
\text { on Gov. Decree } \\
101 \text { of } 2014\end{array}$ & $\begin{array}{l}\text { Production } \\
\text { Capacity } \\
\text { (tonnes yr-1) }\end{array}$ & $\begin{array}{l}\text { Minimum } \\
\text { Production } \\
\text { Capacity } \\
\text { (tonnes yr }{ }^{-1} \text { ) }\end{array}$ & $\begin{array}{c}\text { Waste } \\
\text { Factor per } \\
\text { Production } \\
\text { Capacity }\end{array}$ & $\begin{array}{l}\text { Base Year } \\
\text { Minimum } \\
\text { Generation } \\
\left(\text { tonnes } \mathrm{yr}^{-1}\right)\end{array}$ \\
\hline Fly Ash & $\mathrm{SPP}$ & $69,600,000.00$ & $48,720,000.00$ & 0.07 & $3,185,430.73$ \\
\hline
\end{tabular}




\begin{tabular}{cccccc}
\hline $\begin{array}{c}\text { Waste } \\
\text { Types }\end{array}$ & $\begin{array}{c}\text { Potential Source } \\
\text { of Waste Based } \\
\text { on Gov. Decree } \\
\text { 101 of 2014 }\end{array}$ & $\begin{array}{c}\text { Production } \\
\text { Capacity } \\
\left.\text { (tonnes yr }{ }^{-1}\right)\end{array}$ & $\begin{array}{c}\text { Minimum } \\
\text { Production } \\
\text { Capacity } \\
\left.\text { (tonnes yr }{ }^{-1}\right)\end{array}$ & $\begin{array}{c}\text { Waste } \\
\text { Factor per } \\
\text { Production } \\
\text { Capacity }\end{array}$ & $\begin{array}{c}\text { Base Year } \\
\text { Minimum } \\
\text { Generation } \\
\text { (tonnes yr-1) }\end{array}$ \\
\hline $\begin{array}{c}\text { Bottom } \\
\text { Ash }\end{array}$ & $69,600,000.00$ & $48,720,000.00$ & 0.01 & $445,003.13$ \\
\hline
\end{tabular}

427

428

429

430

431

432

433

434

435

Table 5 FABA generation from MEOG and MAS sectors from 2016 - 2019

\begin{tabular}{ccc}
\hline Year & $\begin{array}{c}\text { FABA Generation from } \\
\left.\text { MEOG Sector (tonnes } \mathrm{yr}^{-1}\right)\end{array}$ & $\begin{array}{c}\text { FABA Generation from } \\
\left.\text { MAS Sector (tonnes } \mathrm{yr}^{-1}\right)\end{array}$ \\
\hline 2016 & $586,932.67$ & $4,399,909.82$ \\
2017 & $3,130,211.40$ & $6,444,145.82$ \\
2018 & $3,313,157.64$ & $7,610,213.15$ \\
2019 & $7,381,414.47$ & $21,764,718.79$ \\
\hline
\end{tabular}

Table 6 Results of normality test of FABA in MEOG and MAS sectors

\begin{tabular}{ccc}
\hline \multirow{2}{*}{ Data Types } & \multicolumn{2}{c}{ Shapiro Wilk } \\
\cline { 2 - 3 } & df & Significance \\
\hline Data from MEOG Sector & 4 & 0.611 \\
Data from MAS Sector & 4 & 0.074 \\
\hline
\end{tabular}

Table 7 Independent T-Test results of MEOG and MAS sector

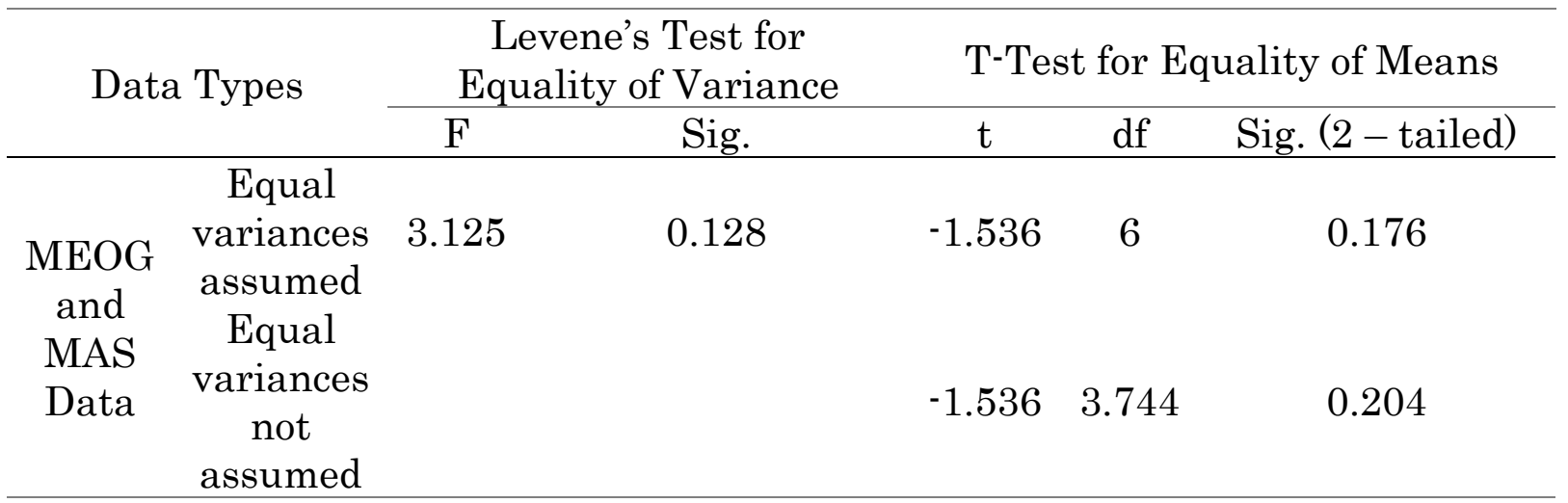

436

437

438

439
Table 8 Prediction Results of FABA generation using maximum and minimum production capacity approaches

\begin{tabular}{ccccc}
\hline Year & $\begin{array}{c}\text { Average FABA } \\
\text { Generation }\end{array}$ & $\mathrm{n}$ & $\begin{array}{c}\text { Maximum FABA } \\
\text { Generation } \\
\left(\text { tonnes yr }^{-1}\right)\end{array}$ & $\begin{array}{c}\text { Minimum FABA } \\
\text { Generation }^{\left(\text {tonnes yr }^{-1}\right)}\end{array}$ \\
\hline 2019 & $5.00 \%$ & 0 & $5,186,334.09$ & $3,630,433.86$ \\
2020 & $5.00 \%$ & 1 & $5,188,927.26$ & $3,632,249.08$ \\
2021 & $5.00 \%$ & 2 & $5,191,521.72$ & $3,634,065.20$ \\
2022 & $5.00 \%$ & 3 & $5,194,117.48$ & $3,635,882.24$ \\
2023 & $5.00 \%$ & 4 & $5,196,714.54$ & $3,637,700.18$ \\
2024 & $5.00 \%$ & 5 & $5,199,312.90$ & $3,639,519.03$
\end{tabular}




\begin{tabular}{ccccc}
\hline Year & $\begin{array}{c}\text { Average FABA } \\
\text { Generation }\end{array}$ & $\mathrm{n}$ & $\begin{array}{c}\text { Maximum FABA } \\
\text { Generation } \\
\left(\text { tonnes yr }^{-1}\right)\end{array}$ & $\begin{array}{c}\text { Minimum FABA } \\
\text { Generation } \\
\left.\text { (tonnes yr }^{-1}\right)\end{array}$ \\
\hline 2025 & $5.00 \%$ & 6 & $5,201,912.55$ & $3,641,338.79$ \\
2026 & $5.00 \%$ & 7 & $5,204,513.51$ & $3,643,159.46$ \\
2027 & $5.00 \%$ & 8 & $5,207,115.77$ & $3,644,981.04$ \\
2028 & $5.00 \%$ & 9 & $5,209,719.33$ & $3,646,803.53$ \\
2029 & $5.00 \%$ & 10 & $5,212,324.19$ & $3,648,626.93$ \\
2030 & $5.00 \%$ & 11 & $5,214,930.35$ & $3,650,451.24$ \\
2031 & $5.00 \%$ & 12 & $5,217,537.81$ & $3,652,276.47$ \\
2032 & $5.00 \%$ & 13 & $5,220,146.58$ & $3,654,102.61$ \\
2033 & $5.00 \%$ & 14 & $5,222,756.65$ & $3,655,929.66$ \\
2034 & $5.00 \%$ & 15 & $5,225,368.03$ & $3,657,757.62$ \\
2035 & $5.00 \%$ & 16 & $5,227,980.72$ & $3,659,586.50$ \\
2036 & $5.00 \%$ & 17 & $5,230,594.71$ & $3,661,416.30$ \\
2037 & $5.00 \%$ & 18 & $5,233,210.00$ & $3,663,247.00$ \\
2038 & $5.00 \%$ & 19 & $5,235,826.61$ & $3,665,078.63$ \\
2039 & $5.00 \%$ & 20 & $5,238,444.52$ & $3,666,911.17$ \\
2040 & $5.00 \%$ & 21 & $5,241,063.75$ & $3,668,744.62$ \\
\hline
\end{tabular}

440

441 Table 9 Prediction results of FABA generation from the MEOG sector

442

\begin{tabular}{cccc}
\hline Year & $\begin{array}{c}\text { Average FABA } \\
\text { Generation Rate }\end{array}$ & $\mathrm{n}$ & $\begin{array}{c}\text { Prediction Results } \\
\text { (tonnes yr }\end{array}$ \\
\hline 2019 & $5.00 \%$ & 0 & $7,381,414.47$ \\
2020 & $5.00 \%$ & 1 & $7,385,105.17$ \\
2021 & $5.00 \%$ & 2 & $7,388,797.72$ \\
2022 & $5.00 \%$ & 3 & $7,392,492.12$ \\
2023 & $5.00 \%$ & 4 & $7,396,188.37$ \\
2024 & $5.00 \%$ & 5 & $7,399,886.46$ \\
2025 & $5.00 \%$ & 6 & $7,403,586.41$ \\
2026 & $5.00 \%$ & 7 & $7,407,288.20$ \\
2027 & $5.00 \%$ & 8 & $7,410,991.84$ \\
2028 & $5.00 \%$ & 9 & $7,414,697.34$ \\
2029 & $5.00 \%$ & 10 & $7,418,404.69$ \\
2030 & $5.00 \%$ & 11 & $7,422,113.89$ \\
2031 & $5.00 \%$ & 12 & $7,425,824.95$ \\
2032 & $5.00 \%$ & 13 & $7,429,537.86$ \\
2033 & $5.00 \%$ & 14 & $7,433,252.63$ \\
2034 & $5.00 \%$ & 15 & $7,436,969.26$ \\
2035 & $5.00 \%$ & 16 & $7,440,687.74$ \\
2036 & $5.00 \%$ & 17 & $7,444,408.08$ \\
2037 & $5.00 \%$ & 18 & $7,448,130.29$ \\
2038 & $5.00 \%$ & 19 & $7,451,854.35$ \\
\end{tabular}




\begin{tabular}{cccc}
\hline Year & $\begin{array}{c}\text { Average FABA } \\
\text { Generation Rate }\end{array}$ & $\mathrm{n}$ & $\begin{array}{c}\text { Prediction Results } \\
\left(\text { tonnes yr }{ }^{-1}\right)\end{array}$ \\
\hline 2039 & $5.00 \%$ & 20 & $7,455,580.28$ \\
2040 & $5.00 \%$ & 21 & $7,459,308.07$ \\
\hline
\end{tabular}

443

444 Table 10 Prediction results of FABA generation from the MAS sector

445

\begin{tabular}{cccc}
\hline Year & $\begin{array}{c}\text { Average FABA } \\
\text { Generation }\end{array}$ & $\mathrm{n}$ & $\begin{array}{c}\text { Prediction Results } \\
\text { (tonnes yr })^{-1}\end{array}$ \\
\hline 2019 & $5.00 \%$ & 0 & $21,764,718.79$ \\
2020 & $5.00 \%$ & 1 & $21,775,601.15$ \\
2021 & $5.00 \%$ & 2 & $21,786,488.95$ \\
2022 & $5.00 \%$ & 3 & $21,797,382.19$ \\
2023 & $5.00 \%$ & 4 & $21,808,280.89$ \\
2024 & $5.00 \%$ & 5 & $21,819,185.03$ \\
2025 & $5.00 \%$ & 6 & $21,830,094.62$ \\
2026 & $5.00 \%$ & 7 & $21,841,009.67$ \\
2027 & $5.00 \%$ & 8 & $21,851,930.17$ \\
2028 & $5.00 \%$ & 9 & $21,862,856.14$ \\
2029 & $5.00 \%$ & 10 & $21,873,787.56$ \\
2030 & $5.00 \%$ & 11 & $21,884,724.46$ \\
2031 & $5.00 \%$ & 12 & $21,895,666.82$ \\
2032 & $5.00 \%$ & 13 & $21,906,614.65$ \\
2033 & $5.00 \%$ & 14 & $21,917,567.96$ \\
2034 & $5.00 \%$ & 15 & $21,928,526.74$ \\
2035 & $5.00 \%$ & 16 & $21,939,491.01$ \\
2036 & $5.00 \%$ & 17 & $21,950,460.75$ \\
2037 & $5.00 \%$ & 18 & $21,961,435.98$ \\
2038 & $5.00 \%$ & 19 & $21,972,416.70$ \\
2039 & $5.00 \%$ & 20 & $21,983,402.91$ \\
2040 & $5.00 \%$ & $21,994,394.61$ \\
\hline
\end{tabular}

446

Table 11 Chemical components of fly ash and bottom ash in Indonesia

448

\begin{tabular}{ccc}
\hline Component & Bottom Ash Results (\%) [11] & Fly Ash Results (\%) [3] \\
\hline $\mathrm{SiO}_{2}$ & 50.03 & 50.90 \\
$\mathrm{Al}_{2} \mathrm{O}_{3}$ & 3.68 & 15.70 \\
$\mathrm{Fe}_{2} \mathrm{O}_{3}$ & 32.88 & 5.80 \\
$\mathrm{CaO}$ & 3.80 & 24.30 \\
$\mathrm{MgO}$ & 4.01 & 4.60 \\
\hline
\end{tabular}



Year

\section{Figure 1 Increase of FABA generation based on maximum industry capacity}

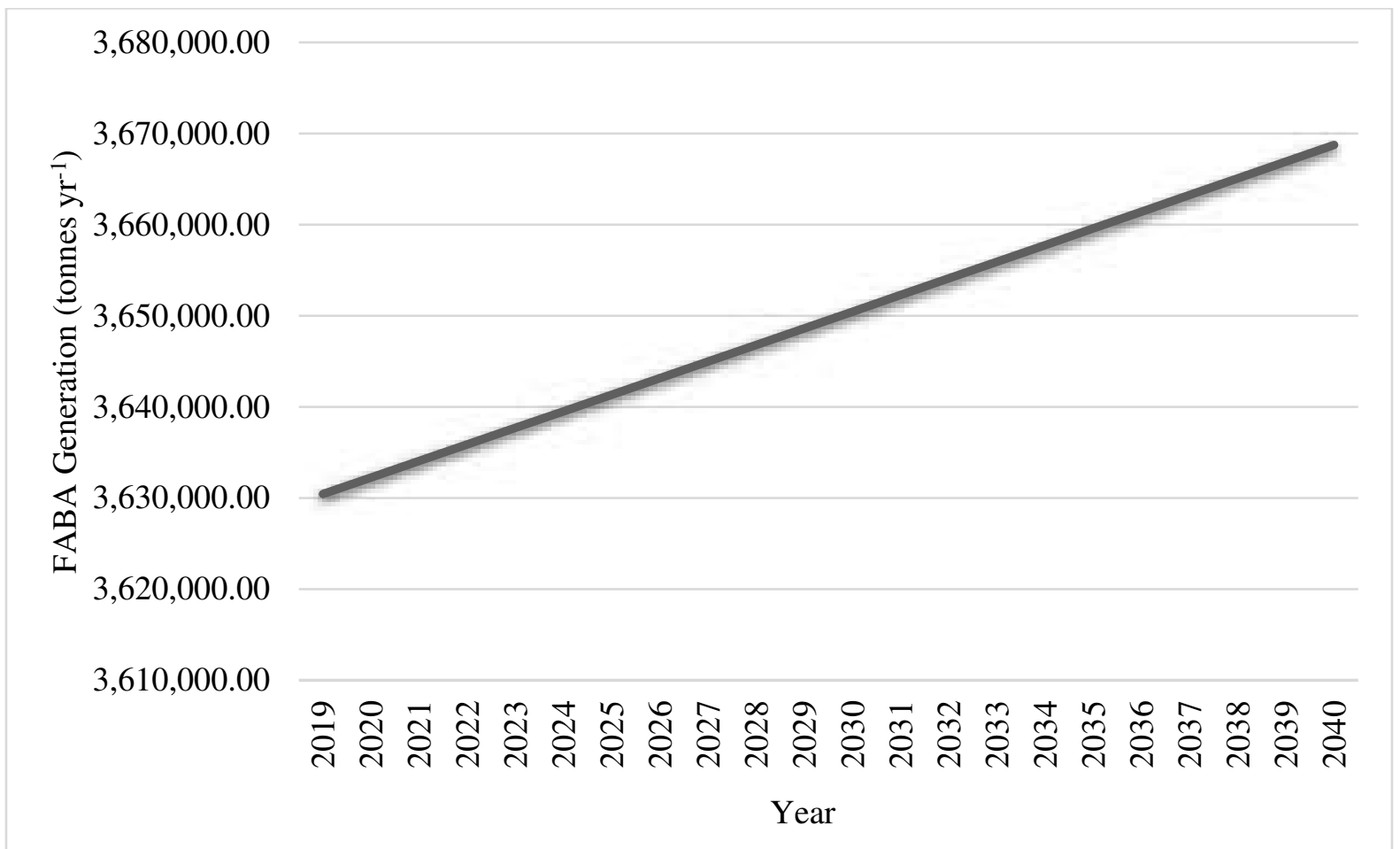

Figure 2 Increase of FABA generation based on minimum industry capacity 
456

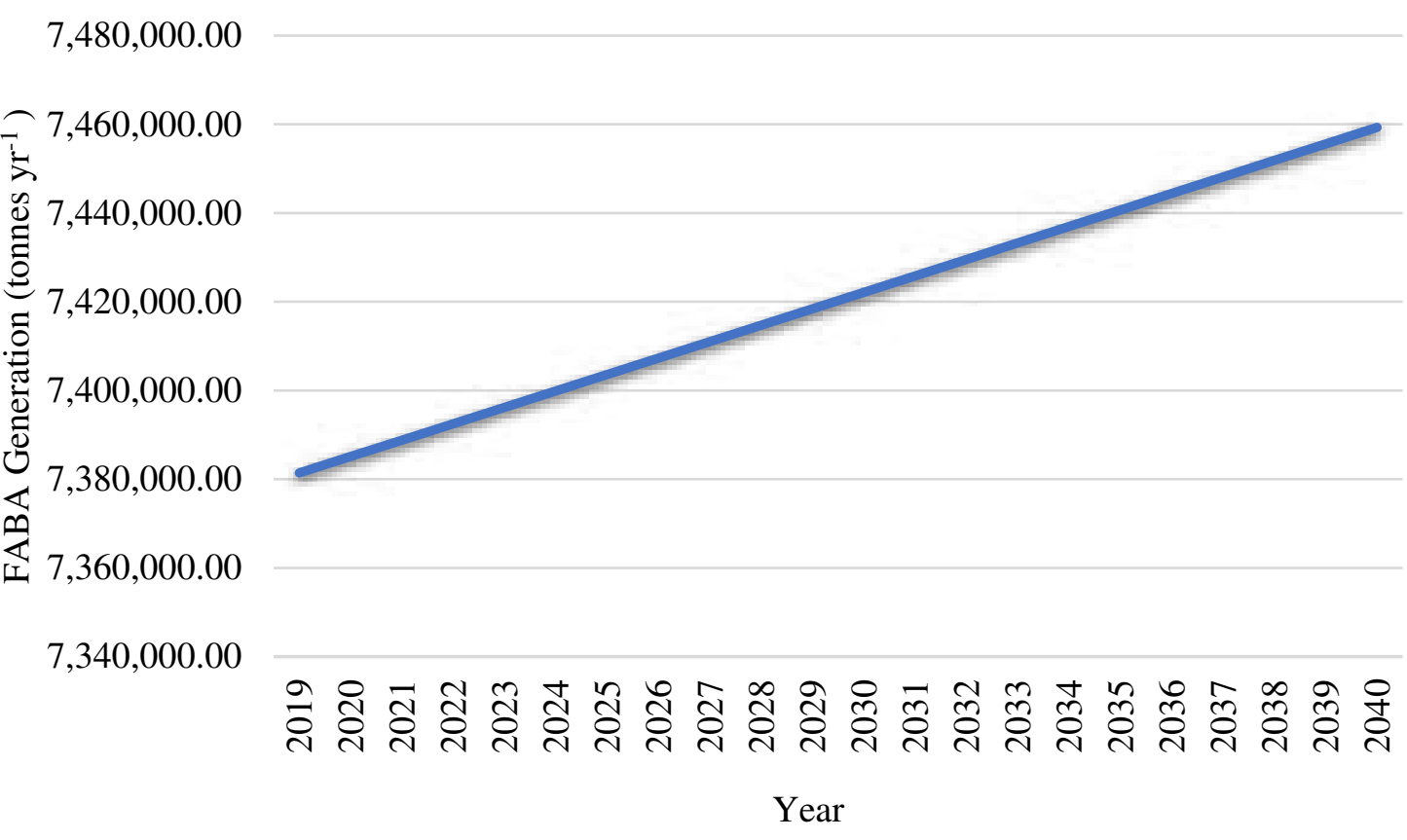

Figure 3 Increase in FABA generation from the MEOG sector

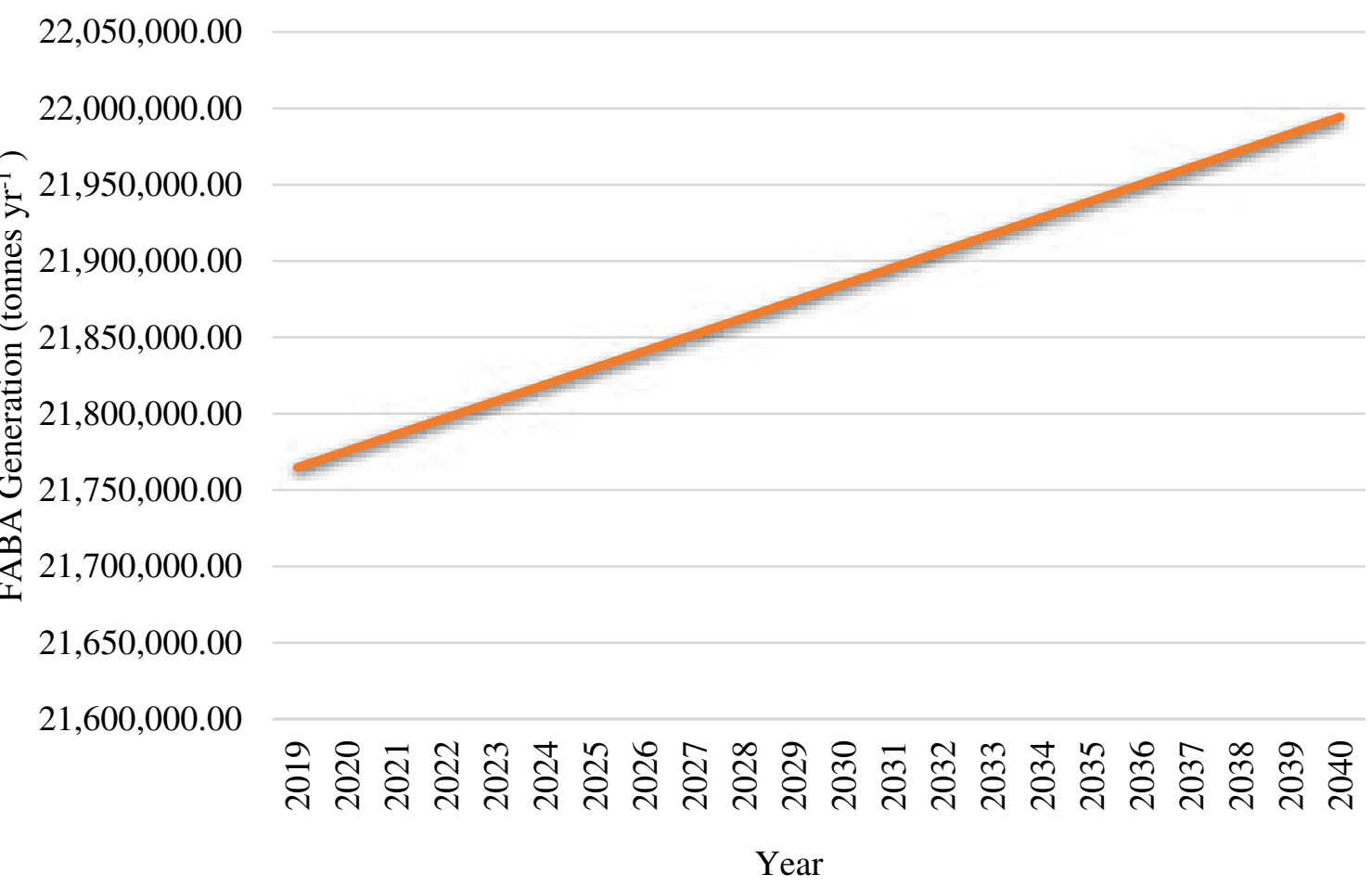

\footnotetext{
Figure 4 Increase in FABA generation from MAS sector
} 


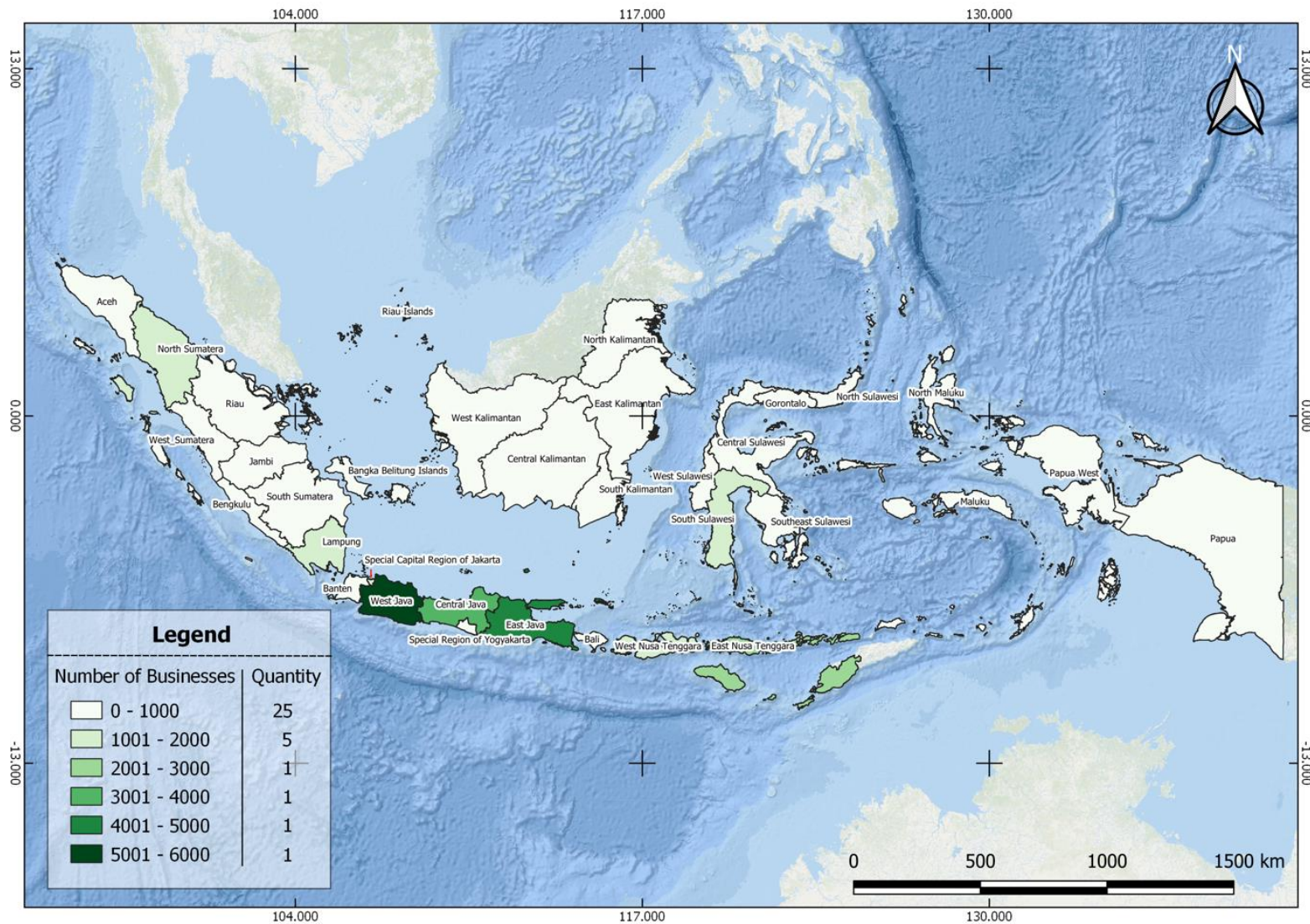

463 Figure 5 Distribution of FABA - producing energy procurement industry in each province in 464 Indonesia

465

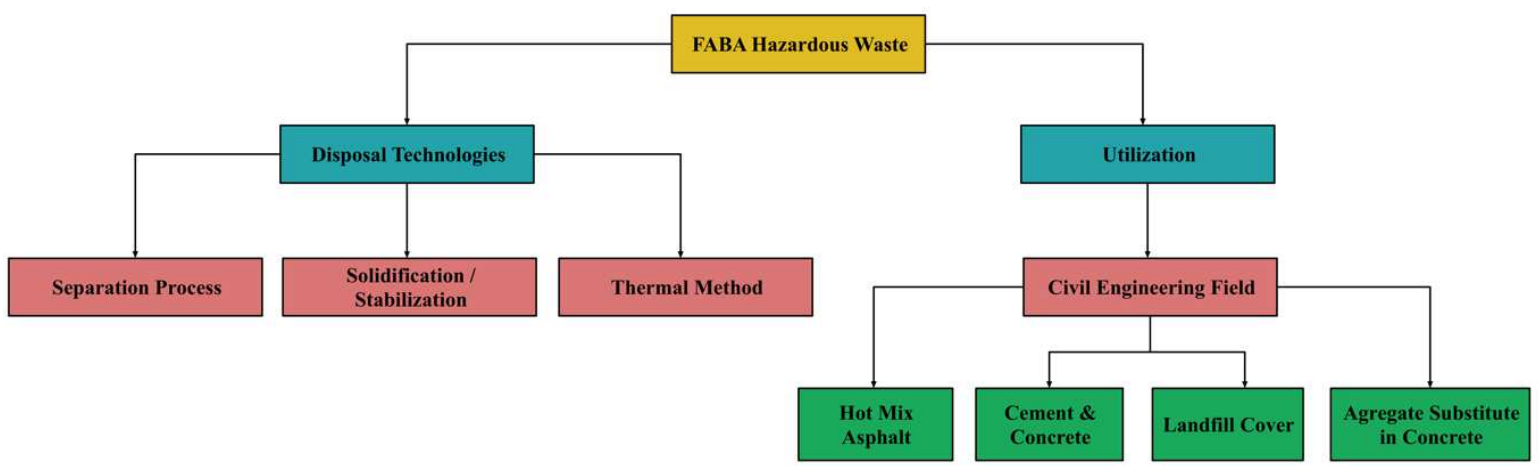

Figure 6 Fly ash and bottom ash waste management scheme 
Figures

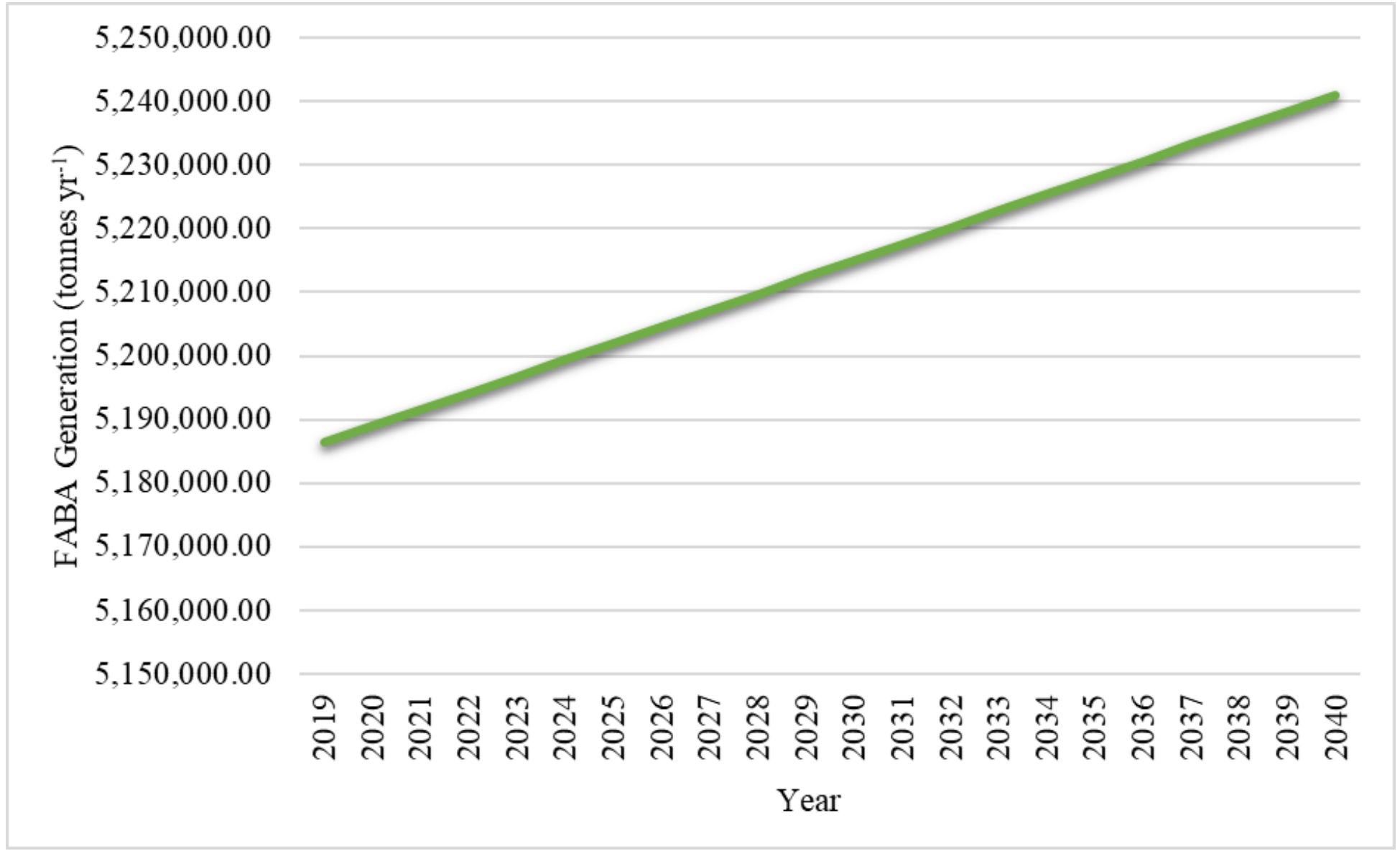

Figure 1

Increase of FABA generation based on maximum industry capacity 


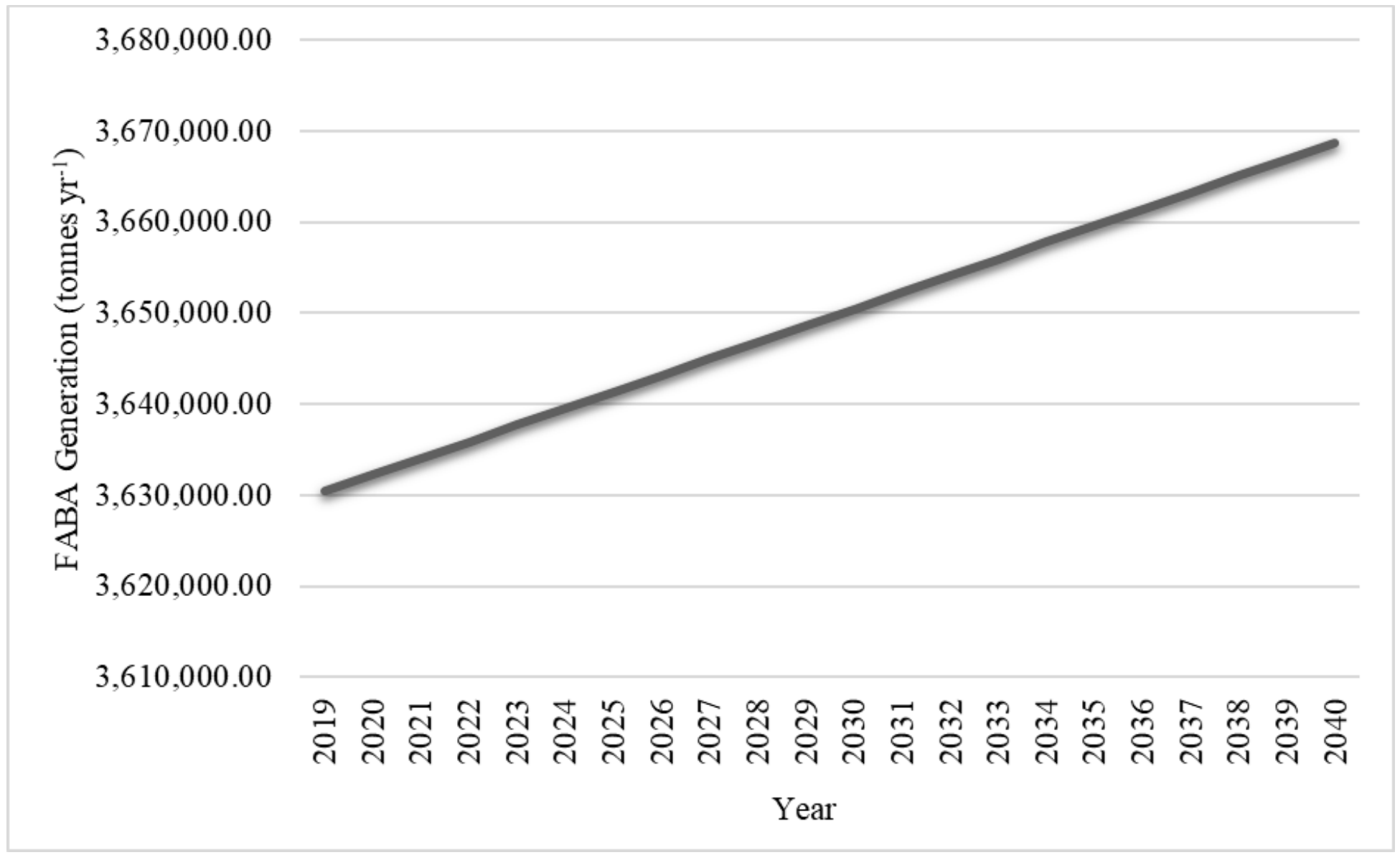

Figure 2

Increase of FABA generation based on minimum industry capacity 


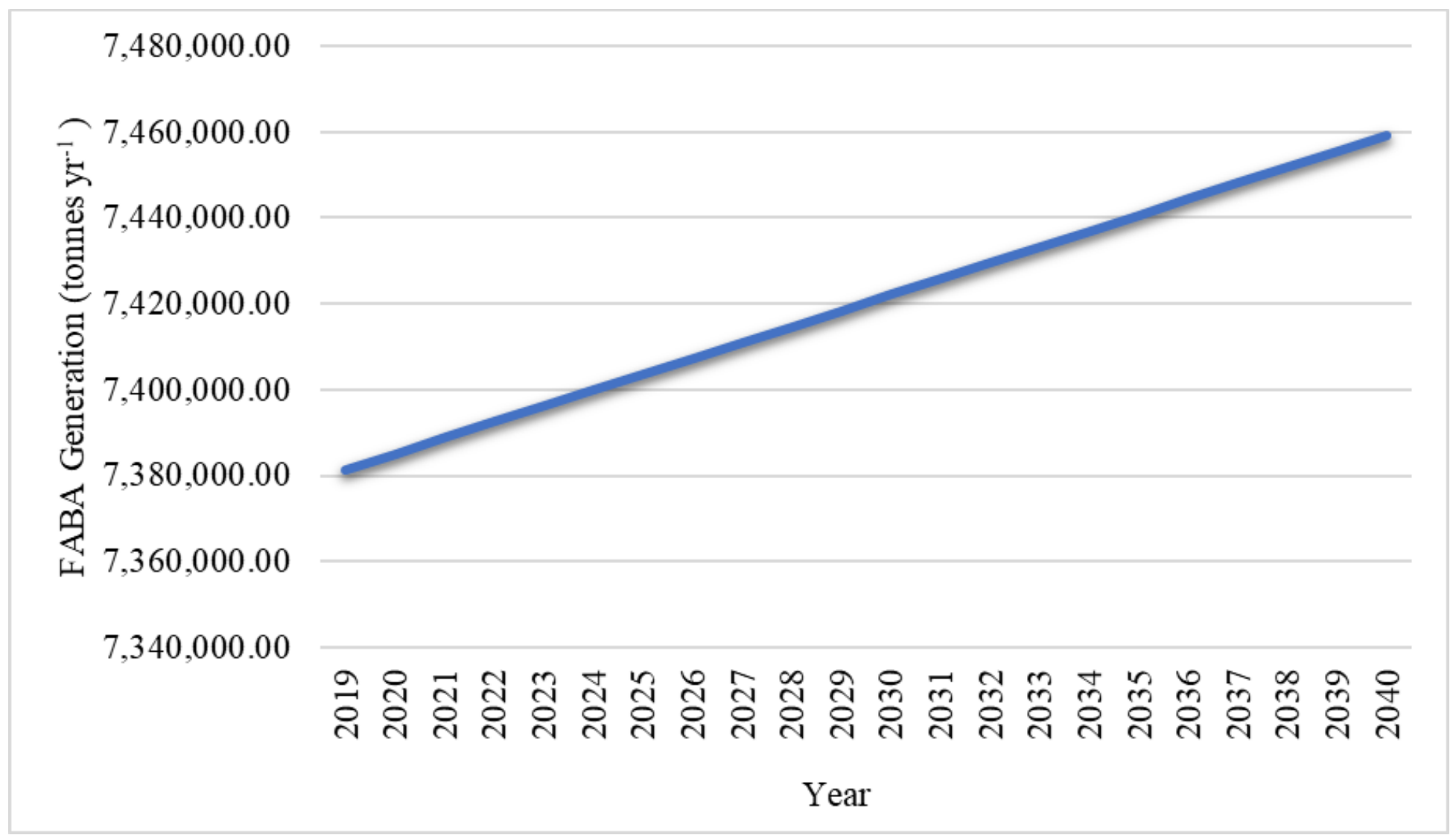

Figure 3

Increase in FABA generation from the MEOG sector 


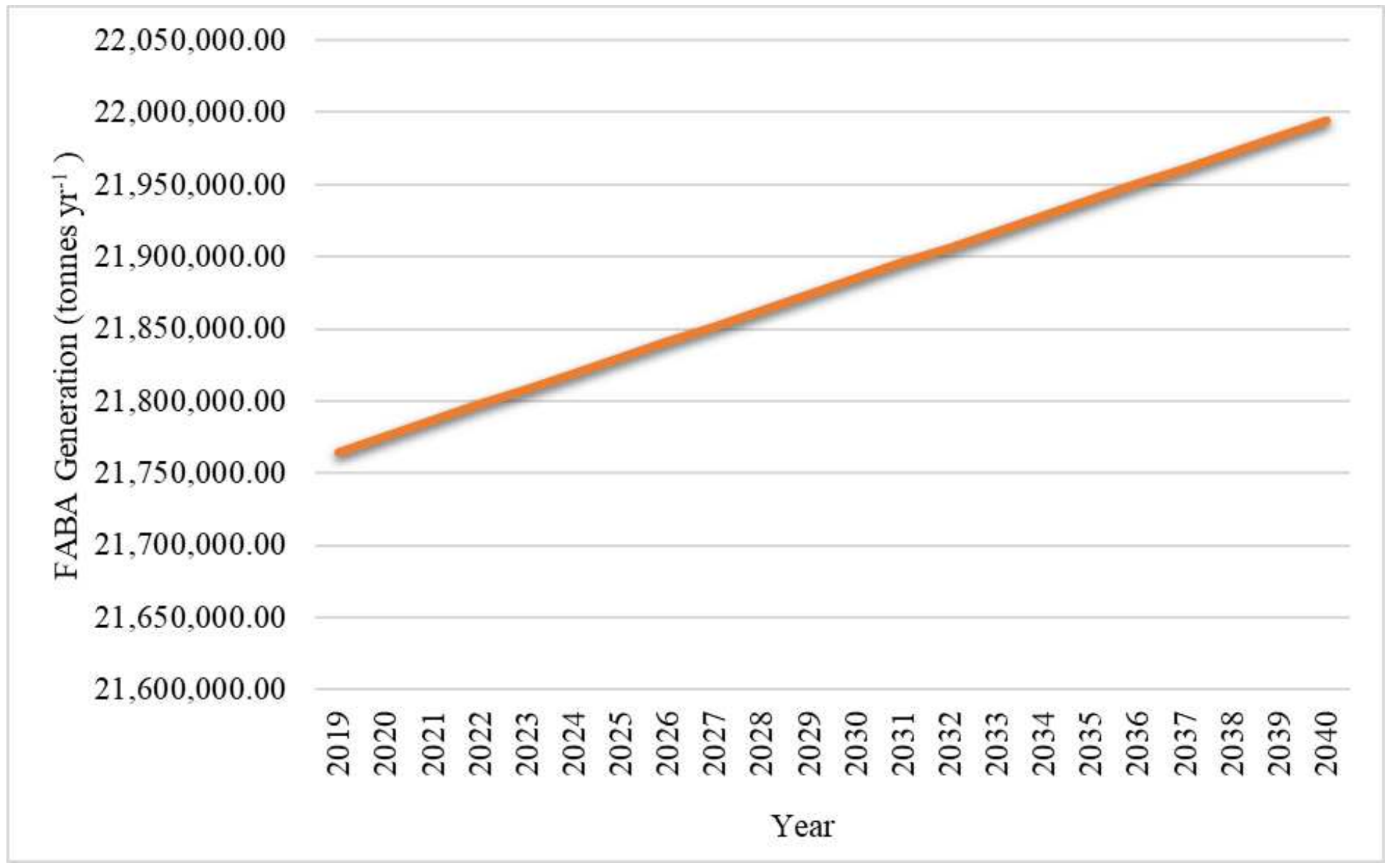

Figure 4

Increase in FABA generation from MAS sector 


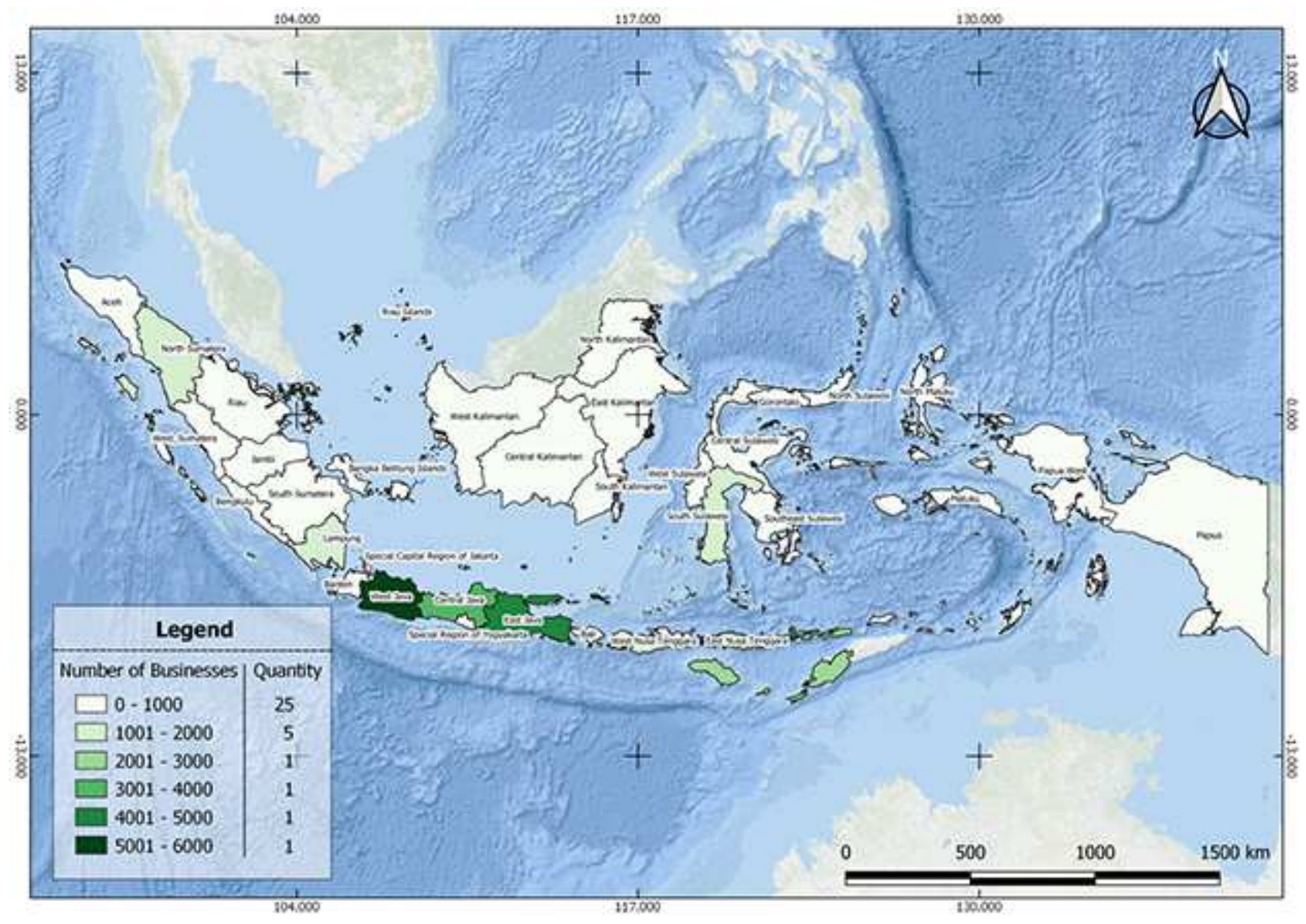

\section{Figure 5}

Distribution of FABA - producing energy procurement industry in each province in Indonesia Note: The designations employed and the presentation of the material on this map do not imply the expression of any opinion whatsoever on the part of Research Square concerning the legal status of any country, territory, city or area or of its authorities, or concerning the delimitation of its frontiers or boundaries. This map has been provided by the authors.

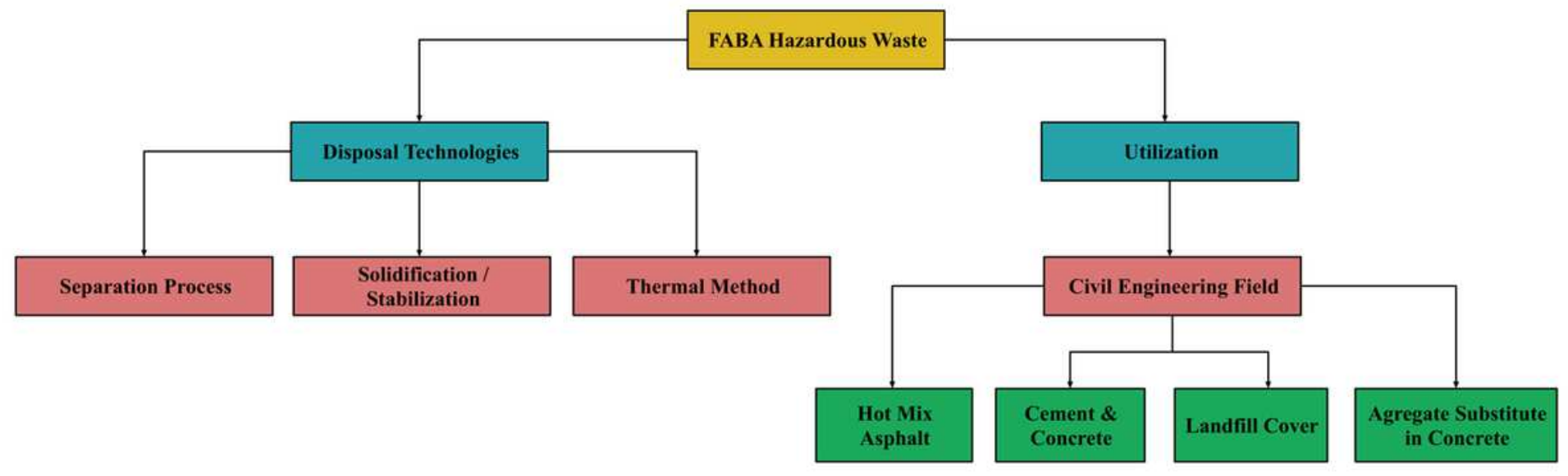

Figure 6

Fly ash and bottom ash waste management scheme 